\title{
4. $\mathrm{A}$ 型ウエルシュ菌エンテロトキシン
}

\author{
植 村 興 \\ 大阪府立大学農学部 獣医公衆衛生学教室 \\ 堺市百舌鳥梅町4-804 干591
}

〔受付：12月24日，1973年〕

\section{まえがき}

ウエルシュ菌食中毒は大量のウエルシュ菌（Clostridium perfringens type A) で污染された食品の提食で 起り，腹痛および下痢をおもな症状とする。

Volunteer に対する人体実験では, vegetative cell を 経口投与すると食中毒をひき起した5)が, cell free の培 養上清の投与では発病しなかつた ${ }^{5,31)}$ 。ウエルシュ菌の 産生する $\alpha$-毒素等既知の 12 種類の毒素33)でも食中毒の 説明がつかず，エンテロトキシンが証明されるまでは, 「感染型」食中毒と考えられていた。Hobbs ら (1953) ${ }^{31)}$ は, 患者便から多数の耐熱性芽胞が検出され，原因食品 はつねに加熱処理をうけていたことから，ウェルシュ菌 のうち耐熱性芽胞形成株が食中毒を起すと報告した。し かしその後, Hall ら (1963) ${ }^{18)}$ の疫学的研究, および Hauschild and Thatcher (1967) ${ }^{27)}$ の人体実験で易熱性 芽胞形成株も食中妻を起すことが判つた。A型ウエルシ ユ菌食中毒の疫学および歴史については Hobbs の詳し い総説がある29,30)。

ウエルシュ菌 vegetative cell を子羊に経口投与す ると下脷をひき起す25)。ウサギ結禁腸管内に投与した vegetative cell は牙胞を形成し, 同時に液体の貯留が起 り結禁腸管は膨張する13)。ウエルシュ菌株のウサギ結禁 腸管膨張能がサル11)やヒト 43)への下溂誘発能と相関する ことも確かめられ, コレラの研究に用いられていた結禁 腸管テストが, りエルシュ菌食中毒の研究にも取り入れ られるようになつた。

Duncan and Strong は芽胞形成培地 (DS 培地)を開 発し9), 芽胞培養液の培養上清および牙胞形成菌の音波 処理抽出液の两方に腸管膨張作用があることを証明した 10)。Hauschild, Niilo and Dorward (1971) も子羊で 同様の結果を得, 腸管膨張には必ずしも生菌を必要とせ ず，芽胞形成時に産生される物質で起ることを確かめ,
その物質を 'Clostridium perfringens enterotoxin' と 命名し, 食中毒起病性の本体であると推定した ${ }^{21,26) 。 ~}$

エンテロトキシンはその後, Stark and Duncan(1971, 1972) 40,42), Hauschild and Hilsheimer'(1971) ${ }^{22)}$, お よび Sakaguchi, Uemura and Riemann ${ }^{38)}$ により精製 された。エンテロトキシンをサルに経口投与すると下痢 をひき起し11,28)，DS 培養液の培養上清をヒトに経口投 与すると食中毒症状を起すことも証明されている43)。エ ンテロトキシンに関しては Hauschild (1972) の総説21) があり，発見の経緯や性状に詳しい。

本論文では，その後急速に進んだ定量法およびウェル シュ菌のエンテロトキシン産生能に関する研究成果を中 心に，精製法や性状についても新たに得られた知見を加 味し，述べる。なお ‘ $C$. perfringens enterotoxin'を文 中ではェンテロトキシンと省略した。

\section{エンテロトキシンの精製}

Stark and Duncan (1971) ${ }^{40)}$ は, NCTC 8798株を DS 培地で 8 時間培養し, 得た牙胞形成菌の音波処理抽出液 および24時間と 48 時間培養後の培養上清を出発材料とし て, Sephadex G·200 のゲルろ過でェンテロトキシンを 初めて精製し, おもに生物活性を調べた。その後の精製 では, エンテロトキシンが音波処理で容易に菌体から抽 出できること, および大量処理が可能なことから, DS 培地で 8 時間前後培養した芽胞形成菌が, 出発材料とし て用いられている。

Hauschild and Hilsheimer (1971) 22) は NCTC 8239 株を用い, Sephadex G-100 のゲルろ過および DEAEcellulose と CM-cellulose のイオン交換クロマトグラフ ィーで精製し, 物理化学的性状を調べた。標品の純度は 97\%, 回収率はイオン交換クロマトグラフィーでの損失 が大きく，25〜30\%であつた。

Stark and Duncan (1972) 42) は, 粗毒素を RNase で 処理した後, Sephadex G-100 のゲルろ過, Cellex T. 
Fluid thioglycolate

Heating at $75 \mathrm{C}$ for $20 \mathrm{~min}$ Incubation $^{a}$ for $18 \mathrm{hr}$

DS medium ${ }^{b}$

Sporulated cells

a All incubations were made at $37 \mathrm{C}$.

b Ingredients ${ }^{47)}$ : Yeast extract (Oriental), $0.2 \%$; proteose peptone (Difco), $1.8 \% ; \mathrm{Na}_{2} \mathrm{HPO}_{4} \cdot 12$ $\mathrm{H}_{2} \mathrm{O}, 1.2 \%$; Na-thioglycolate, $0.05 \%$; soluble starch, $0.4 \%$.

Fig. 1. Preparation of sporulated cells of Clos. tridium perfringens type A NCTC $8798^{9}$

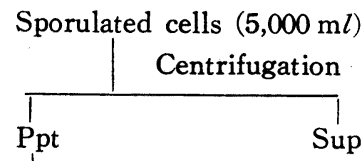

Suspending in $200 \mathrm{~m} l$ of saline

Sonication

Centrifugation

Ppt Sup

$40 \%$ saturation of

$\left(\mathrm{NH}_{4}\right)_{2} \mathrm{SO}_{4}(\mathrm{pH} 7.0$

Centrifugation

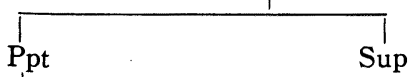

Extraction with $16 \mathrm{~m} l$ of $0.02 \mathrm{M}$ phosphate buffer, $\mathrm{pH} 6.7$ (PB)

Centrifugation

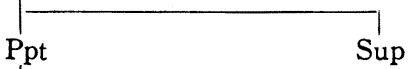

Extraction with $16-20 \mathrm{~m} l$ of $\mathrm{PB}$

Centrifugation

Ppt Sup

Twice-repeated gel filtration

Purified enterotoxin

Fig. 2. Purification of Clostridium perfringens enterotoxin from the sporulated cells ${ }^{38,47)}$. cellulose および hydroxylapatite のクロマトグラフィ 一を用いる改良法で精製した。得られた標品の純度は99 \%以上，回収率は65～75\%であつた。

著者ら ${ }^{38,47)}$ は硫安塩析と Sephadex G-200 によるゲ ルろ過を組み合せた，より簡単な方法で精製した（Fig. 2)。粗毒素中に含まれる低分子たん白質は $40 \%$ 飽和の硫 安塩析で除いた。エンテロトキシンとともに塩析された 高分子たん白質は，エンテロトキシンよりも buffer (0.02 M phosphate buffer, $\mathrm{pH}$ 6.7) に浴解しやすかつ たので，塩析物を少量の bufferで溶解することにより 除去した。硫安塩析と分別溶出で大部分の混在物を除去 した後, Sephadex G-200 でゲルろ過を行い，エンテロ

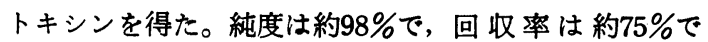
あつた。この方法では浱縮操作や buffer 交換の必要が ないので, 短時間に大量の精製ができる。

いずれも，回収率注芽胞形成菌の音波処理抽出液を基 準に生物活性 (erythemal activity またはマウス MLD) から，純度はディスク電気泳動パターンの面積から算出 されている22,38,42)。エンテロトキシンはゲル 内沈降反 応，ゲルろ過の溶出パターン，および超遠心分析で均一 性が確認されているが，ディスク電気泳動を行うと， major peak $(\mathrm{RM} \doteqdot 0.6)$ より移動度の低い minor peak がすべての標品22,38,42) で出現した。Hauschild and Hilsheimer の標品では移動度の高い第 3 の peak む出

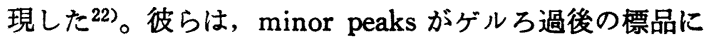
はなく、イオン交換クロマトグラフィー後に出現したの で，エンテロトキシンの一部がイオン交換クロマトグラ フィー中に変化したものと推定しているが，イオン交換 クロマトグラフィーを行わない精製法で得た標品にも同 じ minor component が含まれる38)。これはエンテロ トキシンに近い物理化学的性状をもつ物質であると考え られるが, 生物活性やエンテロトキシンとの関䋆の詳細 は不明である。

\section{エンテロトキシンの性状}

エンテロトキシンは hexose, reducing sugar, および lipid を含まない22)。

紫外部吸収曲線では $250 \mathrm{~m} \mu$ に極小, $278 \sim 280 \mathrm{~m} \mu$ に 極大を示す。 $282 \mathrm{~m} \mu$ にわずかに有を示し, $260 \mathrm{~m} \mu$ の吸 収は示さない22,38,42)。これらのことからエンテロトキシ ンの本体は単純たん白質であると考えられている。 $\mathrm{pH}$ 4.3 亿等電点をもち ${ }^{22,38,42)}$, 分子量は 35,000 前後 22,422 , $\mathrm{S}_{20}, \mathrm{w} 3.08^{42)}$ で, stokes radius は $2.6 \mathrm{~m} \mu^{22)}$ である (Table 1)。

$$
\text { エンテロトキシンを凍結乾燥すると snow-white pow- }
$$


Table 1. Physicochemical properties of Clostridium perfringens enterotoxin.

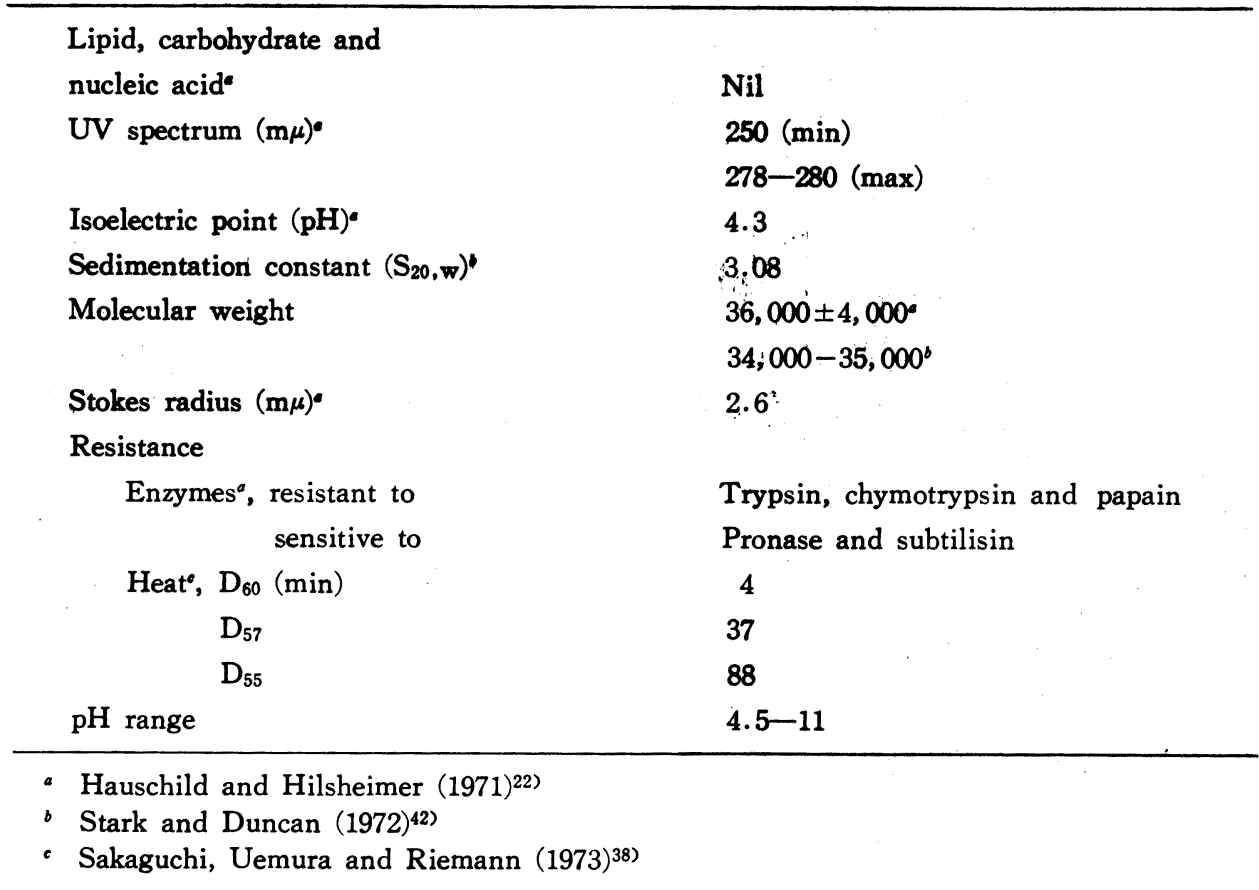

der 状を呈し，水や塩溶液で再び溶解する ${ }^{42)}$ 。凍結融解 を 7 回以上くり返してもマウス致死活性は低下しない。

エンテロトキシンは比較的易熱性で, $50 \mu \mathrm{g} / \mathrm{ml}$ 曟 度 での熱抵抗性を逆受身血球凝集反応で調べた 結 果 ${ }^{38)}$, $\mathrm{D}_{55}$ (55Cでェンテロトキシンの90\%破壊に要する時間） は88分, $D_{57}$ は37分， $D_{60}$ は 4 分であつた。 $100 \mathrm{Cでは}$ 瞬時に破壊され， $\alpha$-毒素33) とは異なつた態度をとる。ア ルカリ ( $\mathrm{pH} 11$ 付近まで) に耐えるか⿱, 酸には弱く, $\mathrm{pH}$ 4 以下では破壊される。一方生菌は $\mathrm{pH} 1.5$ 付近までは 抵抗を示す15,24)。エンテロトキシンの熱および酸に対す る抵抗性が生菌より低いことは，中毒発生機構の究明に 一つの材料を提供する。Jejunal fluid 中では破壊されな (34)。Trypsin, chymotrypsin, papain に対しては抵抗 性を示すが, pronase や subtilisinでは破壊される22)。 Pepsin を $\mathrm{pH} .4 .5$ 以上で作用させても破壊されない。 エンテロトキシンは経口投与でヒト ${ }^{43)}, \quad$ サ ${ }^{11,28)}$, 犬1)

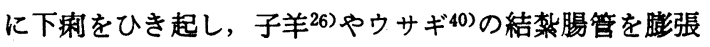
させる。頪羊血球を溶血せず, 抗エンテロトキシン血清 は $\alpha$-毒素のもつ溶血能を中和しない(Fig. 3)。 マウス致 死活性やモルモット皮府反応も， A， B， C，Dおよび E型のウエルシュ菌診断用血清で中和されない40)。

これらのことからエンテロトキシンは，A型ウェルシ 二菌の産生する $\boldsymbol{\alpha}$-毒素と異なり, さらに, B, C, D
およびE型ウエルシュ菌が産生する毒素のいずれとも異 なる物質であると考えられる。

\section{エンテロトキシンの模出および定旦法}

エンテロトキシンが高度に精製されるまでは, エンテ ロトキシンの定量は生物学的方法で行われてきた。生物 活性を通して厳密に定量するには，毒量を標準毒素に対 する相対力価で表示すべきである。しかし現在，標準毒 素は定められていない。生物活性（マウス MLD, erythemal unit 等) 值は, 術式や判定法の違いで変動する。 生物学的定量法は, 反応が必ずしも特異的でないので, 必要に応じて中和反応などでエンテロトキシンの確認を する必要がある。

マウス致死テストは簡単で, 1 時間で結果が出るので 利用価値が高い。生食で稀釈した検体 $0.5 \mathrm{~m} l$ を静脈内 注射すると30分以内に斃死する。30分生残する場合は回 復する。マウスは体重の少ない方が感度が高く, 毒量が 大きいと致死時間が短縮される。しかし致死時間と毒力 との間に，ボッリヌス毒素2,37)や $\alpha$-毒素50)で成立するよ うな相関関係は得られていない。

モルモット皮庙テストは, 反応の直径と既知エンテロ トキシンで作製した標準直線から毒素を定量できる20)。 生食で稀釈した検体 $0.05 \mathrm{ml}$ を脱毛したモルモットの背 部及内に注射する。注射後10～15分で発赤と腫張が顕わ 


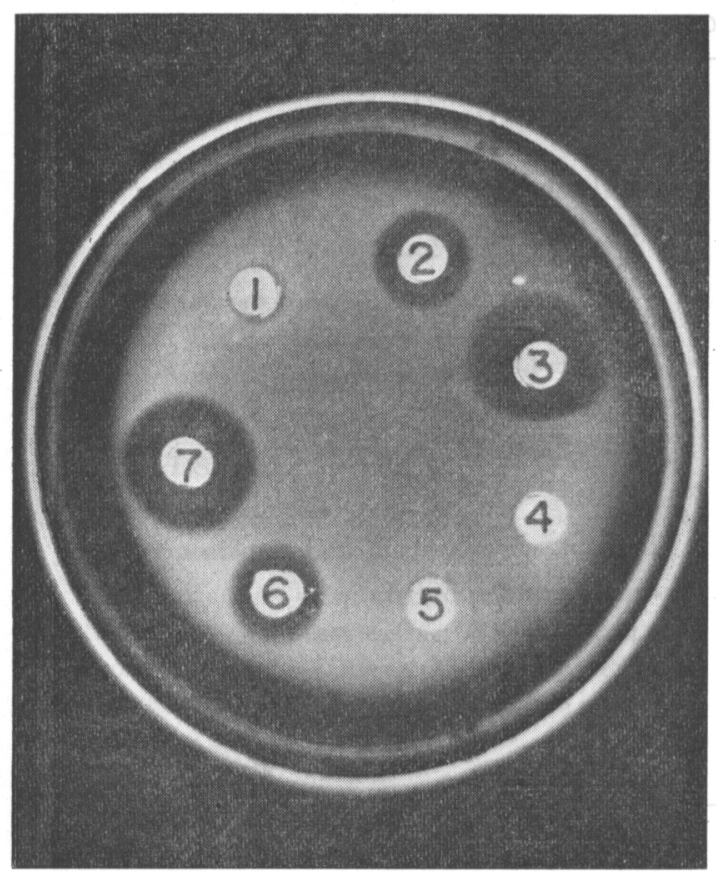

Fig. 3. Hemolytic test for Clostridium perfringens enterotoxin.

Washed sheep red blood cells were used; the blood-agar was prepared according to Harmon and Kautter ${ }^{19}$.

$1)$, enterotoxin $(200 \mu \mathrm{g} / \mathrm{m} l) ; 2)$, culture filtrate of Clostridium perfringens NCTC 8798 grown in fluid thioglycolate medium; 3), phospholipase C (Sigma, $5 \mu \mathrm{g} /$ $\mathrm{m} l)+$ anti-enterotoxin serum; 4), 2) + type A diagnostic serum (Wellcome); 5), 7) + type A diagnostic serum; 6), 2) + anti-enterotoxin serum; 7), phospholipase $\mathrm{C}$.

れ, 腫脤は翌日まで持続する。通常の方法20)では翌日に 発赤腫張の直径を計測する。発赤腫張部位には毛の再生 が見られない20)。直径 $(0.8 \mathrm{~cm} \sim 1.5 \mathrm{~cm}$ の範囲) とエン テロトキシン量の対数との間に直線関係が成立する。検 体注射後30分以内に Evans blue $(2.5 \%, 1 \mathrm{~m} l)$ を静脈 注射すると, 1 時間後には青色円(又は環)が顕われる。

この方法では定量時間を 3 時間に短縮できるが, 検体注 射と Evans blue 注射の interval が青色円の直径を左 右する41)から，検体注射後 Evans blue 注射までの時間 を厳密に同じにすべきである。

ウサギ腸管テストは De のテスト4)として, コレラの 病原性の実験モデルとして開発された。エンテロトキシ ンは $30 \mu \mathrm{g}$ 前後で陽性を示す(Fig. 4)。大がかりな手術

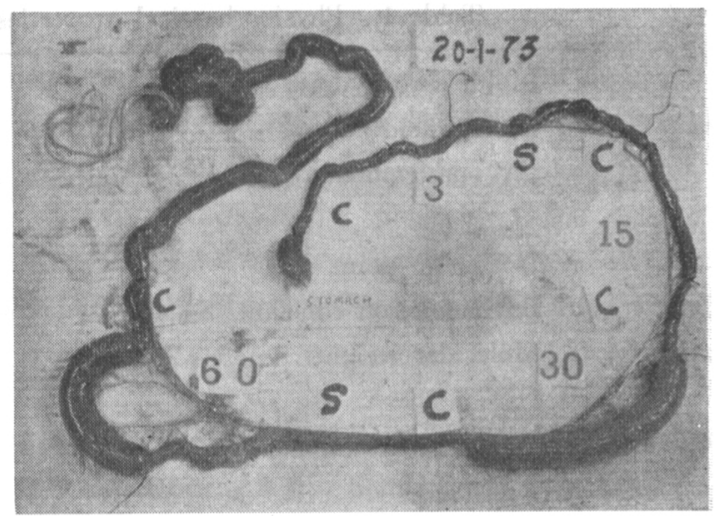

Fig. 4. Rabbit intestinal loop test for Clostridium perfringens enterotoxin.

C, control; S, saline; $60,30,15$ and 3 represents $\mu \mathrm{g}$ of enterotoxin in $3 \mathrm{~m} l$ of saline, respectively.

Loop 60 and 30 were positive; others were negative.

で判定も肉眼的に行らが，再現性は高い。Hauschild and Hilsheimer $(1971)^{23)}$ は, 手術後90分の結禁腸管の 長さと内容液量を求め, $\mathrm{m} l / \mathrm{cm}$ から $6.3 \mu \mathrm{g}$ のエンテ ロトキシンを検出した。90分法は, テスト終了までウサ ギが麻酔下に㧍かれるので人道的だと述べている。手術 は迅速かつ丁寧に行う必要がある。通常検体区の前後に 対照(何も投与しないか生食を投与)区をおき, 対照区が 陽性像を呈した場合は別のウサギを使い，やり直す13)。 著者らの経験で, 回盲結合部近くでは対照区がたびたび 陽性像を呈したので, 回盲結合部から oral 側約 $50 \mathrm{~cm}$ の使用をさけたところ, 判定の混乱がなくなつた。回盲 結合部に近接した部位の使用をさけることは, 合田, 数 野, 佐々木 $(1971)^{17)}$ も指摘している。

エンテロトキシンが精製され, これを用いて特異抗毒 素血清を作製できるようになつた。エンテロトキシンが 免疫学的に単一であるかどうかは今後の問題であるが, エンテロトキシンの定量には, 感度, 精度, 特異性, お よび簡易性に優れた血清学的定量法を用いるべきであ る。

逆受身血球凝集反応 (以下 RPHA と省略) は迅速で 感度が高く, $1 \mathrm{ng} / \mathrm{m} l$ の濃度の毒素を 2 時間で検出でき る45)。検体を $0.25 \%$ に牛血清を含んだ PBS で階段稀釈 し, 抗体で感作した血球と凝集反応を行い, 凝集を示し た最大稀釈の逆数を RPHA 価とし, 同時に行つた既知 濃度のエンテロトキシンの RPHA 価と比較し, 定量す る。階段稀釈数を增すことにより, 一回の操作で広範な 
Table 2. Sensitivity of and time required for different serological and biological methods for detection and quantitation of Clostridium perfringens enterotoxin.

\begin{tabular}{|c|c|c|c|c|}
\hline \multirow[b]{2}{*}{ Test } & \multicolumn{3}{|c|}{ Lowest detectable level } & \multirow{2}{*}{$\begin{array}{l}\text { Time required } \\
\text { for the test }\end{array}$} \\
\hline & $(\mu \mathrm{g})$ & $(\mathrm{m} l)$ & $\begin{array}{c}\text { Concentration } \\
(\mu \mathrm{g} / \mathrm{m} l)\end{array}$ & \\
\hline \multicolumn{5}{|l|}{ Rabbit intestinal loop } \\
\hline (standard) & $15-30$ & 3.0 & $5-10$ & 3 days \\
\hline$(90 \mathrm{~min})^{\bullet}$ & 6.3 & 2.5 & 2.5 & $3 \mathrm{hr}$ \\
\hline \multicolumn{5}{|l|}{ Guinea pig skin } \\
\hline$(8 \mathrm{~mm})^{b}$ & 0.2 & 0.05 & 4 & 2 days \\
\hline$(5 \mathrm{~mm})$ & 0.1 & 0.05 & 2 & $3 \mathrm{hr}$ \\
\hline \multicolumn{5}{|l|}{ Mouse lethality (MLD) } \\
\hline$(15 \mathrm{~g})$ & 1.5 & 0.5 & 3 & $1 \mathrm{hr}$ \\
\hline$(20-22 \mathrm{~g})^{b}$ & 2.8 & 0.3 & 9 & $1 \mathrm{hr}$ \\
\hline \multicolumn{5}{|l|}{ Reversed passive } \\
\hline hemagglutination ${ }^{e}$ & 0.00005 & 0.05 & 0.001 & $3 \mathrm{hr}$ \\
\hline Double diffusion & 0.018 & 0.035 & 0.5 & 3 days \\
\hline Single diffusion & 1.1 & 0.37 & 3 & 2 days \\
\hline Electroimmunodiffusion ${ }^{d}$ & 0.01 & 0.01 & 1 & $6 \mathrm{hr}$ \\
\hline
\end{tabular}

- Hauschild (1970)20)

b Stark and Duncan (1972) ${ }^{42)}$

c Uemura and Riemann (1973) $)^{45}$

d Duncan and Somers $(1972)^{8)}$

浇度域をカバーできるから，湌度の大きく異なる試料を 同時にテストする場合や，䈨度の見当のつかない検体の 定量に適している。他の方法では検出できない微量定量 に威力を発揮する。

Single diffusion テストは, $3 \mu \mathrm{g} / \mathrm{m} l$ から $75 \mu \mathrm{g} / \mathrm{m} l$ 程度のエンテロトキシンを標準直線 (Fig. 5)から求める ので精度は高い。操作も簡単であるが, 沈降線の移動距 離が検液のイオン強度で異なるから ${ }^{16)}$, 検体のイオン強 度不明の場合は定量できない。

Microslide 法による double diffusion テストはブド ウ球菌エンテロトキシンの定量で広く行われている3)。 テンペレートと厚さの均一なテフロンシートの組み合せ で，簡単に操作ができるように改良された ${ }^{48)}$ 。準備操作 が不要で，市販のテンペレートを使えば，わずかな抗血 清と対照用のエンテロトキンだけで実施できる。

Electroimmunodiffusion ${ }^{8)}$ は double diffusion テス トと同程度の感度をもち，かつ迅速な定量法である。し かし電気泳動装置や抗血清の消費量を考虑すると, 多量 の検体の処理には問題がある。

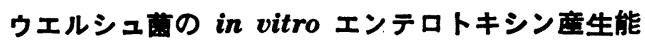

ウエルシュ菌の芽胞形成とエンテロトキシン産生につ いて, Duncan, Strong and Sebald (1972) ${ }^{12)}$ は次の実 験結果を得た。1）エンテロトキシンは vegetative cell の增殖時には産生されず, DS 培地で芽胞形成が起つた 時のみに産生された。2) Spontaneous な変異または acridine orange $や$ nitrosoguanidine 処理による人工変 異で芽胞形成能を失つたウエルシュ菌はエンテロトキシ ンを産生しなかつた。3）80C，10 分間の加熱処理で芽 胞形成能を回復させると, revertant はエンテロトキシ ンを産生した。DS 培地中での芽胞形成とエンテロトキ シン産生の time course を調べた著者らの実験結果 (6) によると，芽胞は培養 4 時間目頃から急激に增加し， 6 〜8時間で最高に達した。全培養液のエンテロトキシン は芽胞数と平行して增加した。培養上清中のエンテロト キシンは引き続き增加し，24時間後に最高に達した。幼 若培養液を音波処理すると上清中のエンテロトキシンは 增加したが，24時間あるいは48時間の培粯液を音波処理 してもエンテロトキシンの増加はなかつた。芽胞を鏡検 すると， 8 時間培養では sporangium であるが，24時間 培養では free spore となつていた。 


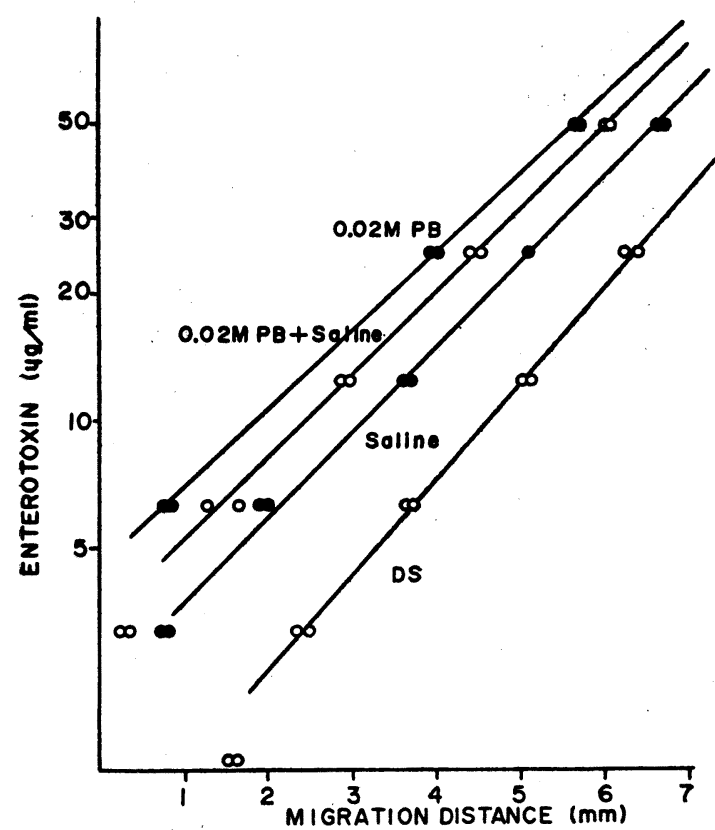

Fig. 5. Standard curves for single gel immunodiffusion test.

Diluents: $0.02 \mathrm{M} \mathrm{PB}, 0.02 \mathrm{M}$ phosphate buffer ( $\mathrm{pH} 7.0) ; 0.02 \mathrm{M} \mathrm{PB}+$ saline, $0.02 \mathrm{M}$ phosphate buffer $(\mathrm{pH} 7.0)+0.85$ $\% \mathrm{NaCl}(1: 1)$; Saline, $0.85 \% \mathrm{NaCl}$; DS, Duncan Strong medium.

以上の実験結果から，エンテロトキシンは芽胞形成に 伴つて産生され，芽胞形成の初期には sporangium 内に 蓄積されている。エンテロトキシンはその後徐々に上清 中に遊離され, free spore の内部には存在しないものと 考えられる。Duncan (1973)6) む同様の実験結果を得 た。Sporangium 内に, 芽胞とは別に, エンテロトキシ ンの aggregate と思われる paracrystalline inclusion が観察されている7)。

Niilo (1973) ${ }^{35)}$ は Hobb's serotype 1 型から13型の 13 株と, 型不明の 2 株の計 15 株の $\mathrm{A}$ 型ウェルシュ菌のエ ンテロトキシン産生を, immunodiffusion, モルモット 皮庙テストおよび子羊結禁腸管テストで調べた。12株が エンテロトキシンを産生し, 免疫学的に, NCTC 8239 株のエンテロトキシンと同一であつた。生物活性を示す が血清反応を示さない株は見られなかつた。著者ら46)の 成績では，A型ウエルシュ菌14株中 5 株がエンテロトキ シンを産生し, 産生量は $0.5 \mu \mathrm{g} / \mathrm{m} l$ から $26 \mu \mathrm{g} / \mathrm{ml}$ と 菌株間で差が見られた。NCTC 8798 株では $80 \mu \mathrm{g} / \mathrm{m} l^{6}$ ) から $100 \mu \mathrm{g} / \mathrm{m} l^{16)}$ に達する。

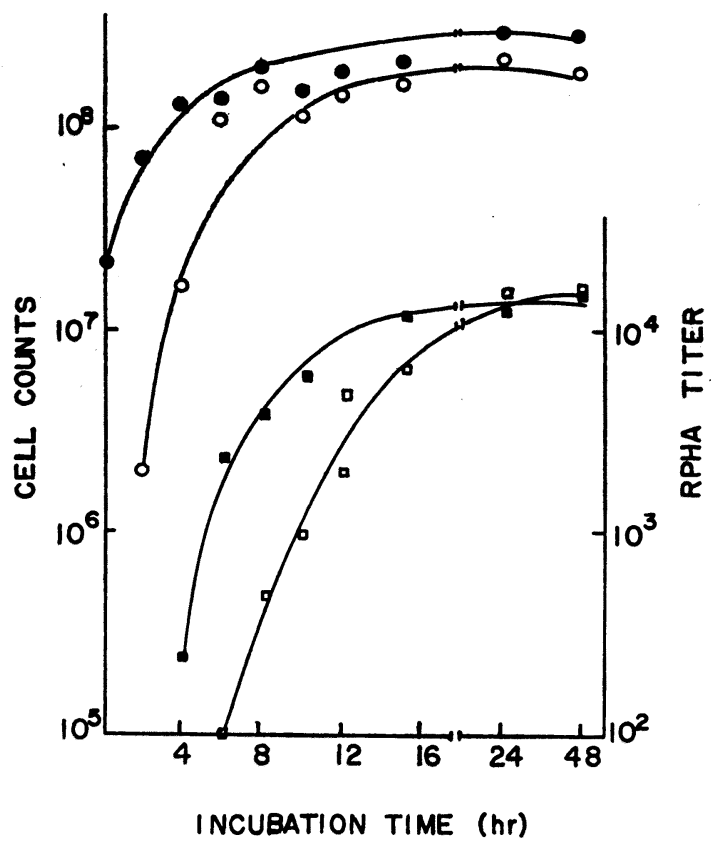

Fig. 6. Sporulation and enterotoxin formation by Clostridium perfringens type A NC. TC 8798 in DS medium ${ }^{46}$.

Closed circles, total cell counts per $\mathrm{m} l$; open circles, spore counts per $\mathrm{m} l$; closed squares, enterotoxin in whole culture; open squares, enterotoxin in supernatant. 1, 000 RPHA titer corresponds to approx. $1 \mu \mathrm{g} / \mathrm{m} l$ of enterotoxin.

$\mathrm{B}$ 型, $\mathrm{C}$ 型, $\mathrm{D}$ 型, および $\mathrm{E}$ 型のウエルシュ菌はエン テロトキシンを産生しなかつた ${ }^{46)}$ 。さらに多数の菌株に ついて検討する必要があるが，現在のところ，A型以外 のウエルシュ菌のエンテロトキシン産生の報告はない。

エンテロトキシン産生実験には Fig. 1 亿示す培養方 法9）用いた ${ }^{46)}$ 。DS 培養は 8 時間の代りに一夜培養を 行い, RPHA でエンテロトキシンを定量した。この方 法では $\mathrm{A}$ 型菌14株中 3 株が発育しなかつたが，TG 培地 に接種直後に行う $75 \mathrm{C} ， 20$ 分の加熱処理を省くと全株が 発育した。しかし, 同し NCTC 8798 株の stock culture から出発しても，加熱処理を省くと，位相差顕微鏡下で count した芽胞数は加熱処理をした場合の $1 / 3$ に減少し， エンテロトキシン産生量は $0.1 \mu \mathrm{g} / \mathrm{m} l$ と，1/260に低下し た。S-79株でも同じ傾向がみられた。Nishida, Seo and Nakagawa $(1969)^{36)}$ は, 同し芽胞形成培地 (Ellner's medium ${ }^{14)}$ ) でも芽胞形成量が研究者によつて異なるの は前培䓹の違いによるのだろうと推定している。Vege- 
tative cell や芽胞をマウスに経口投与しても毒性を示さ ないが，80Cで15分間 heat-shock した牙胞は毒性を示 したとの報告もある ${ }^{399}$ 。加熱処理の奻果がすべての株に あてはまるのかどうか， $75 C ， 20$ 分が最適なのかどうか など, mechanism の究明とも合わせて, さらに検討す る必要がある。

\section{あとがき}

ウエルシュ菌の芽胞形成率には大差があり, DS 培地 でも $5 \%$ 以下か $590 \%$ 以上に及ぶ株もある。芽胞の熱抵 抗性も菌株間に差があり, Hobbs $5^{31)}$ の報告以来食中 毒とも関連して, 論議の的になつてきた。現在, エンテ ロトキシンの産生には芽胞形成が必要だが, 芽胞形成に は必ずしもエンテロトキシンの合成を必要としないと考 えられている。しかし, 芽胞形成菌の音波処理抽出液 1 $\mathrm{mg}$ 中には $100 \mu \mathrm{g}$ ものエンテロトキシンが含まれ6), sporangium の構成分としてのエンテロトキシンの存在 は無視できない。エンテロトキシンが芽胞形成に関与 し，さらに形成された芽胞の性質（たとえば耐熱性）と関 連しているのではなかろうか。

ウエルシュ菌食中毒は, 米国では例年,患者数で, 全食 中毒の $30 \%$ 前後を占める ${ }^{49}$ が，わが国では少ない32)。今 後本中毒に対する関心が高まり, エンテロトキシン検査 を加えた新しい方法が確立されると,わが国でも，ウエル シュ菌食中毒の報告事例の增加が予想される。A型ウェ ルシュ菌にエンテロトキシン産生株と非産生株があり, かつ産生量に差のあることは, 食中毒発生機構の究明 や，検査法および予防法確立の資料を得るためにも，広 範なウエルシュ菌のエンテロトキシン産生能調査の必要 性を示唆している。ウエシルュ菌食中毒は食品中で産生 されたエンテロトキシンで起るのではなく, 食品ととも に摄食した生菌が腸管内で芽胞形成時に産生したエンテ ロトキシンで起ると考えられるから, 診断には食品およ び便から分離した菌株のエンテロトキシン産生能を調べ る必要がある。

エンテロトキシンの定量は, 特異性の高い抗血清が得 られるようになつたので, 血清学的方法を適用すべきで ある。しかしエンテロトキシン産生能を mass screening する際は, 今の段階では, 抗原的に異なつたエンテロト キシンの存在の可能性があるので, 生物学的検出法も并 用するのが望ましい。

稿を終わるに当り, 本文に引用した研究の御指導と, 論文の御校閲を載いた阪口玄二教授に深謝いたします。

\section{文嘀}

1) Bartlett, M. L., Walker, H. W., and Ziprin, R. (1972): Use of dogs as an assay for Clostridium perfringens enterotoxin. Appl. Microbiol., 23, 196-197.

2) Boroff,D. A., and Fleck, U. (1966): Statistical analysis of a rapid in vivo method for the titration of the toxin of Clostridium botulinum. J. Bacteriol., 92, 1580-1581.

3) Casman, E. P., Bennet, R. W., Dorsey, A. E., and Stone, J. E. (1969): The microslide gel double diffusion test for the detection and assay of staphylococcal enterotoxins. Health Lab. Sci., 6, 185-198.

4) De, S. N., and Chatterrje, D. N. (1953): An experimental study of the mechanism of action of Vibrio cholerae on the intestinal mucous membrane, J. Pathol. Bacteriol., 66, 559-562.

5) Dische, F. E., and Elek, S. D. (1957): Experimental food poisoning by Clostridium welchii, Lancet, ii, 71-74.

6) Duncan, C. L. (1973): Time of enterotoxin formation and release during sporulation of Clostridium perfringens type A. J. Bacteriol., 113, 932-936.

7) Duncan, C. L., King, G. J., and Frieben, W. R. (1973) : A paracrystalline inclusion formed during sporulation of enterotoxin-producing strains of Clostridium perfringens type A. J. Bacteriol., 114, 845-859.

8) Duncan, C. L., and Somers, E. B. (1972): Quantitation of Clostridium perfringens type A enterotoxin by electroimmunodiffusion. Appl. Microbiol., 24, 801-804.

9) Duncan, C. L., and Strong, D. H. (1968): Improved medium for sporulation of Clostridium perfringens Appl. Microbiol., 16, 8289.

10) Duncan, C. L., and Strong, D. H. (1969): Ileal loop fluid accumulation and production of diarrhea in rabbits by cell-free products of Clostridium perfringens. J. Bacteriol., 100, 86-94.

11) Duncan, C. L., and Strong, D. H. (1971): Clostridium perfringens type A food poisoning, I. Response of the rabbit ileum as an indication of enteropathogenicity of strains of Clostridium perfringens in monkeys. Infect. Immun., 3, 167-170.

12) Duncan, C. L., Strong, D. H., and Sebald, M. (1972): Sporulation and enterotoxin production by mutants of Clostridium perfrin- 
gens. J. Bacteriol., 110, 378-391.

13) Duncan, C. L., Sugiyama, H., and Strong, D. H. (1968): Rabbit ileal loop response to strains of Clostridium perfringens. J. Bacteriol., 95, 1560-1566.

14) Ellner, P. D. (1956): A medium promoting rapid quantitative sporulation in Clostridium perfringens. J. Bacteriol., 71, 495-496.

15) Fischer, L. H., Strong, D. H., and Duncan, C. L. (1970): Resistance of Clostridium perfringens to varying degrees of acidity during growth and sporulation. J. Food Sci., 35, 91-95.

16) Genigeorgis, C., Sakaguchi, G., and Riemann, H. (1973): Assay methods for Clostridium perfringens type $\mathrm{A}$ enterotoxin. Appl. Microbiol., 26, 111-115.

17）合田 朗, 数野勇造, 佐々木正五 (1971)：腸管 結禁ループ法の実験手技。感染症学雑誌, 45, 196-201.

18) Hall, H. E., Angelotti, R., Lewis, K. H., and Foster, M. J. (1963): Characteristics of Clostridium perfringens strains associated with food poisoning and food-borne disease. J. Bacteriol., 85, 1094-1103.

19) Harmon, S. M., and Kautter, D. A. (1970): Method for estimating the presence of Clostridium perfringens in food. Appl. Microbiol., 20, 913-918.

20) Hauschild, A. H. W. (1970) : Erythemal activity of the cellular enteropathogenic factor of Clostridium perfringens type A. Can. J. Microbiol., 16, 651-654.

21) Hauschild, A. H. W. (1971): Clostridium perfringens enterotoxin. J. Milk Food Technol., 34, 596-599.

22) Hauschild, A. H. W., and Hilsheimer, R. (1971): Purification and characteristics of the enterotoxin of Clostridium perfringens type A. Can. J. Microbiol., 17, 1425-1433.

23) Hauschild, A. H. W., Hilsheimer, R., and Rogers, C. G. (1971): Rapid detection of Clostridium) perfringens enterotoxin by a modified ligated intestinal loop technique in rabbits. Can. J. Microbiol., 17, 1475-1476.

24) Hauschild, A. H. W., Hilsheimer, R., and Thatcher, F. S. (1967): Acid resistance and infectivity of food-poisoning Clostridium perfringens. Can. J. Microbiol., 13, 1041-1047.

25) Hauschild, A. H. W., Niilo, L., and Dorward, W. J. (1967): Experimental enteritis with food poisoming and classical strains of Clostridium perfringens type $\mathrm{A}$ in lambs. J. Infect. Disease, 117, 379-385.
26) Hauschild, A. H. W., Niilo, L., and Dorward, W. J. (1971): The role of enterotoxin in Clostridium perfringens type A enteritis. Can. J. Microbiol., 17, 987-991.

27) Hauschild, A. H. W., and Thatcher, F. S. (1967): Experimental food poisoning with heat-susceptible Clostridium perfringens type A. J. Food Sci., 32, 467-469.

28) Hauschild, A. H. W., Walcroft, M. J., and Campbell, W. (1971): Emesis and diarrhea induced by enterotoxin of Clostridium per. fringens type $\mathrm{A}$ in monkeys. Can. J. Microbiol., 17, 1141-1143.

29) Hobbs, B. C. (1965): Clostridium welchii as a food poisoning organism. J. Appl. Bacteriol., 28, 74-82.

30) Hobbs, B. C. (1969): In Food-borne infections and intoxications. Edited by Riemann, H., pp. 131-173. New York and London, Academic Press.

31) Hobbs, B. C., Smith, M. E., Oakley, C. L., Warack, G.H., and Cruickshank, J.C. (1953): Clostridium welchii food poisoning. J. Hyg., 51, 75-101.

32）厚生省食品衛生課（1973）：昭和47年食中毒発生 状況。食品衛生研究, 23, 906-919.

33）村田良介。(1972)：タンパク毒素。上，256-323 頁, 東京, 講談社。

34) Niilo, L. (1973): Fluid secretary response of bovine thiry jejunal fistula to enterotoxin of Clostridium perfringens. Infect. Immun., $7,1-4$.

35) Niilo, L. (1973): Antigenic homogeneity of enterotoxin from different agglutinating serotypes of Clostridium perfringens. Can. J. Microbiol., 19, 521-524.

36) Nishida, S., Seo, N., and Nakagawa, M. (1969): Sporulating, heat resistance, and biological properties of Clostridium perfringens. Appl. Microbiol., 17, 303-309.

37) Sakaguchi, G., Sakaguchi, S., and Kondo, H. (1968): Rapid bioassay for Clostridium botulinum type-E toxins by intraveneous injection into mice. Jap. J. Med. Sci. Biol., 21, 369378.

38) Sakaguchi, G., Uemura, T., and Riemann, H.: A simplified method for purification of Clostridium perfringens type A enterotoxin. Appl. Microbiol., 27, 762-767.

39) Schulze, J. A., Nakamura, M., and Jutila, J. W. (1969): Pathogenicity of Clostridium perfringens-fed germ-free mice. Bacteriol. Proc., 69.

40) Stark, R. L., and Duncan, C. L. (1971): 
Biological characteristics of Clostridium perfringens type A enterotoxin. Infect. Immun., 4, 89-96.

41) Stark, R. L., and Duncan, C. L. (1972): Transient increase in capillary permeability induced by Clostridium perfringens type A enterotoxin. Infect. Immun., 5, 147-150.

42) Stark, R. L., and Duncan, C. L. (1972): Purification and biological properties of Clostridium perfringens type A enterotoxin. Infect. Immun., 6, 662-673.

43) Strong, D. H., Duncan, C. L., and Perna, G. (1971): Clostridium perfringens type A food poisoning. II. Response of the rabbit ileum as an indication of enteropathogenicity of strains of Clostridium perfringens in human beings. Infect. Immun, 3, 171-178.

44) Torres, M. J.: personal communication.

45) Uemura, T., and Riemann, H. (1973): Reversed passive hemagglutination for determination of Clostridium perfringens enterotoxin.
Abstr. Ann. Meet. Amer. Soc. Microbiol., 22.

46) Uemura, T., Sakaguchi, G., and Riemann, H. P. (1973): In vitro production of Clostridium perfringens enterotoxin and its detection by reversed passive hemagglutination. Appl. Microbiol., 26, 381-385.

47）植村 興, 阪口玄二; 山本博之(1973)：ウエル シュ菌エンテロトキシンの精製。日細菌誌，28， 47.

48) Untermann, F. (1972): Diagnostik der Staphylokokkenlebensmittel-vergiftung. Die Fleishwirtshaft, 52, 500-503.

49) U. S. Dept. Health, Education and Welfare (1972): Foodborne outbreaks, Annual summary 1971, 4.

50) Yamamoto, A., Ito, A., Soda, S., Sato, H., Sadahiro, S., and Murata, R. (1972): Bioassay for $\alpha$-toxin of Clostridium perfringens using survival time in mice. Jap. J. Med. Sci. Biol., 25, 15-23. 